\title{
KETAHANAN PAPAN PARTIKEL TERHADAP SUHU TINGGI, SERAPAN AIR DAN PERILAKU PATAH
}

\author{
Dian Sestining $\mathbf{A y u}^{1}$, Edi Kurniadi ${ }^{2}$ \\ ${ }^{1}$ DIV TPPIS/Departemen Teknik Sipil, Sekolah Vokasi, Universitas Gadjah Mada, Indonesia \\ Email: 1diansestining@ymail.com, dian.sestining@ugm.ac.id \\ ${ }^{2}$ DIII Teknik Sipil/Departemen Teknik Sipil/Sekolah Vokasi, Universitas Gadjah Mada, Indonesia \\ Email: 2edikur2005@yahoo.com
}

\begin{abstract}
Wood is widely used for structural and non-structural purposes. In non-structural purpose, wood is used, among others, as furniture, parquet (wood floor), partitions and so on. In line with the decreasing availability of wood, the price of wood is becoming increasingly expensive. In certain uses, substitute materials such as particle boards have been started to use. Particle boards are generally composed of certain wood powder wastes. This study aimed to look for alternative materials for building particle boards from coconut shells. The particle boards to be tested were composed of coconut shells with the addition of certain wood powder which is added with certain percentage. Particle boards were printed with a certain size, given certain pressure and tested for their physical properties. The physical properties of the particle boards tested included particle density, water absorption, dry flexural modulus, and dry bending fracture modulus. The results showed that the best mixture composition capable of producing density values, water absorption, fracture modulus and optimum modulus of elasticity were found in the proportion of mixtures of 70-90\% coconut shell particles and 30-10\% wood particles.
\end{abstract}

Keywords: particle board, density, broken modulus, high temperature 


\section{PENDAHULUAN}

\section{Latar Belakang}

Kayu dalam industri konstruksi digunakan secara luas sebagai material struktural berupa kuda-kuda, gording, kasau, balok, kolom dan sebagainya. Sebagai material nonstruktural kayu digunakan sebagai partisi, pelapis plat lantai, mebeler dan sebagainya. Dalam perkembangannya, ketersediaan kayu yang merupakan bahan organik semakin terbatas. Keterbatasan persediaan inilah yang menjadikan harga kayu menjadi semakin mahal, sehingga penggunaan bahan alternatif sebagai pengganti kayu mulai banyak digunakan. Material dari baja dan beton digunakan sebagai alternatif pada komponen struktural dan papan partikel digunakan sebagai alternatif pengganti komponen non-struktural.

Papan partikel atau particle board adalah material alternatif pengganti kayu yang tersusun dari butiran-butiran atau partikel dari kayu dengan atau tanpa penambahan bahan lain yang direkatkan dengan perekat tertentu dan dalam proses perekatannya diberi tekanan tertentu untuk mendapatkan kepadatan yang diinginkan. Papan partikel umumnya digunakan sebagai komponen nonstruktural seperti partisi dan mebel. Untuk mendapatkan harga material yang kompetitif, bahan penyusun papan partikel umumnya terbuat dari limbah seperti limbah cangkang kopi, sekam padi, kulit kakao, batang tebu dan lainnya. Bila digunakan bahan penyusun dari kayu umumnya digunakan partikel kayu yang berharga murah, misalnya kayu albasia, kayu randu, kayu nangka dan lain-lainnya.

Di semua daerah di wilayah Indonesia, banyak terdapat pohon kelapa dan pabrik pengolahan daging kelapa yang diolah menjadi minyak serta dimanfaatkan oleh masyarakat sekitar. Dalam proses pengolahannya hanya daging kelapa yang diproses menjadi minyak. Sementara daging kelapa dikonsumsi, hasil sampingan berupa limbah batok kelapa tidak bisa dimanfaatkan.

Penelitian ini mencoba memanfaatkan limbah batok kelapa sebagai alternatif bahan penyusun papan partikel. Mengingat sifat batok kelapa yang keras dan getas, papan partikel yang akan dibuat masih tetap menambahkan partikel dari kayu sebagai campurannya. Partikel atau serbuk kayu yang digunakan di sini adalah serbuk kayu sengon, kayu nangka dan kayu glugu. Persentase partikel batok kelapa yang digunakan dalam komposisi pembuatan papan partikel adalah 100\%, 90\%, 80\%, 70\%, 60\% dan 50\%. Untuk merekatkan partikel-partikel batok kelapa dan serbuk kayu digunakan perekat yang banyak digunakan di pasaran (resin dan hardener). Sifat fisik papan partikel yang diuji antara lain adalah kerapatan partikel, serapan air, modulus elastisitas lentur kering dan modulus patah lentur kering. 


\section{Keaslian Penelitian}

Penelitian tentang papan partikel berbahan dasar limbah sudah pernah dilakukan oleh beberapa peneliti sebelumnya, antara lain Isroful (2011) melakukan penelitIan tentang papan partikel yang berbahan dasar batang pohon pisang, Iskandar (2009) meneliti papan partikel berbahan dasar utama batok kelapa kopi, Dewojati (2014) melakukan penelitian berbahan dasar batok kelapa keong mas dengan campuran serbuk kayu mahoni dan kayu randu.

Dari beberapa penelitian sejenis yang disebutkan di atas terlihat bahwa belum pernah dilakukan penelitian mengenai pemanfaatan limbah batok kelapa sebagai bahan penyusun papan partikel dengan penambahan limbah serbuk kayu sengon, kayu nangka dan kayu glugu.

\section{Tujuan Penelitian}

Penelitian yang dilakukan memiliki tujuan seperti yang tersebut di bawah ini.

a. Mengetahui nilai kerapatan partikel, serapan air, modulus elastisitas lentur kering dan modulus patah lentur kering pada papan partikel dengan komposisi 100\% partikel batok kelapa,

b. Mengetahui nilai kerapatan partikel, serapan air, modulus elastisitas lentur kering dan modulus patah lentur kering pada papan partikel dengan komposisi 90\%, 80\%, 70\%, 60\% dan $50 \%$ partikel batok kelapa sementara sisanya hingga mencapai $100 \%$ adalah tambahan sebuk kayu sengon, kayu nangka dan kayu glugu,

c. Mencari komposisi campuran terbaik antara partikel batok kelapa, serbuk kayu dan perekat yang memberikan sifat fisik yang paling optimal.

\section{Tinjauan Pustaka dan Landasan Teori}

\section{Batok kelapa}

Batok kelapa merupakan bagian keras yang melindungi daging buah dan isinya. Bersifat keras, tajam dan sukar membusuk. Untuk mendapatkan partikel dengan ukuran yang diinginkan, batok kelapa dihancurkan dan kemudian disaring dengan saringan tertentu (lolos saringan 4,75 dan tertahan 1,18$)$.

\section{Papan partikel}

Papan partikel adalah papan buatan yang terbuat dari limbah penggergajian kayu atau bahan selulosa lainnya yang diikat dengan perekat dengan bahan tambahan lainnya, dalam 
proses tekanan dan suhu yang cukup tinggi dalam waktu tertentu (Sulastiningsih, 2014). Menurut SNI 03-2105-2006 papan partikel adalah hasil pengempaan panas campuran partikel kayu atau bahan berlignoselulosa lainnya dengan perekat organik serta bahan lain. Dalam proses pembuatan papan partikel banyak hal yang harus diperhatikan, antara lain butiran partikel yang digunakan, kadar air pertikel dan jenis perekat yang digunakan. Limbah kayu atau bahan selulusa lainnya disarankan berbutir tidak terlalu besar (lolos saringan ukuran 4,75 dan tertahan saringan 1,18) dan seragam. Limbah kayu atau bahan selulosa lain yang akan menghasilkan papan partikel berkualitas baik apabila memiliki kadar air antara 4\% - 8\% (Iskandar, 2009). Proses pengempaan dan proses perekatan akan sulit dilakukan pada kadar air yang tinggi karena akan membutuhkan volume perekat yang lebih besar. Sebaliknya, kadar air yang terlalu rendah juga kurang baik karena menghasilkan papan partikel yang cenderung rapuh dan mudah patah serta mudah mengalami retak (Iskandar, 2009). Kadar air bahan baku penyusun papan partikel perlu dikendalikan, karena sangat dipengaruhi kondisi udara sekelilingnya dan bersifat higroskopis, artinya akan menyerap air dari air atau udara di sekelilingnya (SNI 03-2105-2006).

Papan partikel diklasifikasikan dalam beberapa penggolongan berdasarkan beberapa hal seperti yang tersebut di bawah ini.

a. Klasifikasi papan partikel berdasarkan metode pemberian tekanan dan pembuatannya.

b. Klasifikasi papan partikel berdasrkan jenis perekat dan penggunaannya.

c. Klasifikasi papan partikel berdasarkan kerapatannya.

d. Klasifikasi partikel berdasarkan struktur papan.

Menurut Maloney (1977) terdapat beberapa faktor yang mempengaruhi sifat-sifat papan partikel, faktor tersebut adalah jenis kayu, macam dan ukuran partikel, jenis dan jumlah perekat, kadar air dan distribusinya, kesejajaran partikel dan pelapisan menurut kerapatan papan, profil dan bahan tambahan. Sementara itu menurut Kollman and Wilfred. (1975), sifat fisik dan mekanik papan partikel dipengaruhi oleh beberapa faktor yaitu jenis kayu, tipe dan ukuran partikel, tipe dan jumlah perekat, penyebaran dan perekatan partikel, kadar air serta proses pembuatannya.

\section{Perekat}

Menurut Prayitno (1995) perekat (adhesive, resin, glue, mucilage, binder) adalah bahan yang mempunyai sifat perekatan yang mampu merekat atau menjadikan satu bahan-bahan 
yang direkat dengan cara penempelan atau persatuan permukaan akibat dari aksi gaya-gaya sekunder dan primer.

Perekat dikelompokkan menjadi dua kelompok yaitu perekat alam dan perekat buatan atau sintetis. Perekat alam merupakan perekat yang dihasilkan oleh alam baik oleh hewan besar, serangga kecil, tumbuh-tumbuhan dan bahan yang telah tersedia di alam tanpa pengolahan dan penggunaan teknologi yang rumit untuk mempersiapkannya.

\section{Pengempaan}

Proses pengempaan atau pemberian tekanan tertentu pada proses perekatan dan pengerasan papan partikel bisa dilakukan dalam dua cara yaitu pengempaan panas dan pengempaan dingin. Pada penelitian ini pengempaan dilakukan dengan cara pengempaan dingin.

Pengempaan dingin dilakukan pada pembentukan mat. Tujuan pembentukan mat adalah untuk menyiapkan bentuk dasar yang tetap dari partikel dan siap untuk dikempa (Kollman and Wilfred 1975).

\section{Landasan Teori}

Pengujian yang dilakukan pada papan partikel adalah untuk mengetahui fisik dan mekanik papan partikel. Sifat-sifat papan partikel yang dihasilkan kemudian dibandingkan dengan standar industri yang berlaku, apakah papan partikel yang dihasilkan telah memenuhi persyaratan industri ataukah tidak. Pengujian yang dilakukan adalah uji kerapatan, uji serapan air setelah direndam 24 jam, uji modulus elastisitas dan uji modulus patah.

Pengujian kerapatan dilakukan terhadap benda uji berukuran $10 \mathrm{~cm}$ x $20 \mathrm{~cm}$ x $1 \mathrm{~cm}$. Kerapatan papan partikel dihitung dengan rumus berikut

$$
\begin{aligned}
& D=\frac{W_{u}}{V_{M}} \text { (1) dengan } \\
& \mathrm{D}=\text { kerapatan }\left(\mathrm{gr} / \mathrm{cm}^{3}\right) \\
& \mathrm{W}_{\mathrm{U}}=\text { berat kering udara }(\mathrm{gr}) \\
& \mathrm{V}_{\mathrm{M}}=\text { volume contoh uji kering udara }\left(\mathrm{cm}^{3}\right) .
\end{aligned}
$$

Pengujian serapan air dilakukan pada benda uji berukuran $5 \mathrm{~cm}$ x $5 \mathrm{~cm}$ x $1 \mathrm{~cm}$. Benda uji direndam selama 24 jam. Serapan air papan partikel dihitung dengan rumus berikut

$$
\begin{aligned}
P_{a}(\%)=\frac{\left(W_{t}-W_{s}\right)}{W_{s}} \times 100 \% \text { (2) dengan } & \mathrm{P}_{\mathrm{a}}=\text { serapan air }(\%) \\
& \mathrm{W}_{\mathrm{t}}=\text { berat awal benda uji }(\mathrm{gr}) \\
& \mathrm{W}_{\mathrm{s}}=\text { berat contoh setelah perendaman }(\mathrm{gr}) .
\end{aligned}
$$


Pengujian keteguhan lengkung statik dilakukan pada benda ui berukuran $10 \mathrm{~cm}$ x $20 \mathrm{~cm}$ x $1 \mathrm{~cm}$. Keteguhan lengkung statik dinyatakan dengan menggunakan nilai modulus patah (Modulus of Rupture/M $M_{O R}$ ) dan nilai modulus elastisitas (Modulus of Elasticity/M $O E$ ). Modulus patah dianalisa dengan rumus berikut

$$
\begin{array}{ll}
M_{O R}=\frac{3 B \cdot S}{2 \cdot L \cdot T^{2}} \quad \text { (3) dengan } & \mathrm{M}_{\mathrm{OR}}=\text { modulus patah }\left(\mathrm{kg} / \mathrm{cm}^{2}\right) \\
& \mathrm{B}=\text { beban maksimum }(\mathrm{kg}) \\
& \mathrm{S}=\text { jarak sangga }(\mathrm{cm}) \\
& \mathrm{L}=\text { panjang benda uji }(\mathrm{cm}) \\
& \mathrm{T}=\text { tebal benda uji }(\mathrm{cm}) .
\end{array}
$$

Modulus elastisitas (MOE) dapat dihitung dengan persamaan sebagai berikut

$$
\begin{aligned}
M_{O E}=\frac{S^{3}}{14 L \cdot T^{3}} \times \frac{\Delta B}{\Delta D} \quad \text { (4) dengan } \quad & \mathrm{M}_{\mathrm{OE}}=\text { modulus elastisitas }\left(\mathrm{kg} / \mathrm{cm}^{2}\right) \\
\mathrm{S} & =\text { jarak sangga }(\mathrm{cm}) \\
\mathrm{L} & =\text { panjang benda uji }(\mathrm{cm}) \\
\mathrm{T} & =\text { tebal benda uji }(\mathrm{cm}) \\
\Delta \mathrm{B} & =\text { selisih beban }\left(\mathrm{B}_{1}-\mathrm{B}_{2}\right)(\mathrm{kg}) \\
\Delta \mathrm{D} & =\text { defleksi yang terjadi pada selisih beban } \\
& (\mathrm{cm}) .
\end{aligned}
$$

\section{Hipotesa}

Papan partikel yang tersusun dari limbah batok kelapa dan serbuk kayu sengon, kayu nangka dan kayu randu memiliki sifat-sifat fisik dan mekanik yang sama dengan papan partikel lainnya.

\section{BAHAN DAN METODE PENELITIAN}

\section{Bahan Penelitian}

Bahan-bahan yang digunakan dalam penelitian ini adalah batok kelapa, serbuk kayu sengon, kayu nangka dan kayu randu, serta perekat partikel (epoxi/resin dicampur dengan hardener). 


\section{Alat Penelitian}

Alat-alat yang digunakan terbagi menjadi dua jenis, yaitu

a. Alat-alat untuk membuat papan partikel, seperti satu set saringan (ukuran partikel lolos saringan 4,75 dan tertahan pada saringan 1,18), timbangan, wadah pencampur yang dilengkapi pengaduk, cetakan untuk membuat mat papan partikel, alat press/pemberi tekanan, gergaji dan jangka sorong.

b. Alat-alat untuk melakukan pengujian kerapatan partikel, serapan air, modulus patah dan modulus elastisitas.

\section{Prosedur Penelitian}

Dalam melaksanakan penelitian ada beberapa tahap yang dilakukan, yaitu.

a. Batok kelapa dihancurkan dengan cara ditumbuk kasar secara manual, kemudian disaring dengan satu set saringan. Partikel batok kelapa yang digunakan adalah partikel yang lolos saringan 4,75 dan tertahan saringan 1,18.

b. Batok kelapa dicuci dengan air dan dikeringkan.

c. Membuat komposisi bahan penyusun papan partikel berdasarkan persentase batok kelapa dan serbuk kayu yang digunakan. Dilakukan penimbangan partikel cangang dan serbuk kayu sesuai komposisi kemudian dicampurkan dalam kondisi kering.

d. Campuran partikel batok kelapa dan serbuk kayu ditambahkan perekat (1/3 berat campuran partikel kering) dan diaduk.

e. Campuran partikel batok kelapa, serbuk kayu dan perekat kemudian dicetak dengan ukuran tertentu $(10 \mathrm{~cm} \times 20 \mathrm{~cm} \times 1,5 \mathrm{~cm})$.

f. Bahan papan partikel dikempa dengan tekanan $1 \mathrm{~kg} / \mathrm{cm}^{2}$.

g. Pengkondisian selama 7 hari.

\section{Analisa Hasil}

Papan partikel dibuat berdasarkan tujuan pengujian. Spesifikasi dan jumlah benda uji dapat dilihat pada Tabel 1 berikut ini. 
Tabel 1. Jumlah dan Spesifikasi benda Uji

\begin{tabular}{|c|c|c|c|c|c|c|}
\hline No. & Benda uji & Kerapatan & Serapan air & $\begin{array}{c}\text { Modulus } \\
\text { patah }\end{array}$ & $\begin{array}{l}\text { Modulus } \\
\text { lentur }\end{array}$ & $\begin{array}{c}\text { Suhu } \\
\text { tinggi }\end{array}$ \\
\hline \multirow[t]{6}{*}{1} & \multicolumn{6}{|c|}{ \% partikel batok kelapa terhadap partikel kayu sengon } \\
\hline & $90 \%$ & 3 buah & 3 buah & 3 buah & 3 buah & 3 buah \\
\hline & $80 \%$ & 3 buah & 3 buah & 3 buah & 3 buah & 3 buah \\
\hline & $70 \%$ & 3 buah & 3 buah & 3 buah & 3 buah & 3 buah \\
\hline & $60 \%$ & 3 buah & 3 buah & 3 buah & 3 buah & 3 buah \\
\hline & $50 \%$ & 3 buah & 3 buah & 3 buah & 3 buah & 3 buah \\
\hline \multirow[t]{6}{*}{2} & \multicolumn{6}{|c|}{$\%$ partikel batok kelapa terhadap partikel kayu nangka } \\
\hline & $90 \%$ & 3 buah & 3 buah & 3 buah & 3 buah & 3 buah \\
\hline & $80 \%$ & 3 buah & 3 buah & 3 buah & 3 buah & 3 buah \\
\hline & $70 \%$ & 3 buah & 3 buah & 3 buah & 3 buah & 3 buah \\
\hline & $60 \%$ & 3 buah & 3 buah & 3 buah & 3 buah & 3 buah \\
\hline & $50 \%$ & 3 buah & 3 buah & 3 buah & 3 buah & 3 buah \\
\hline \multirow[t]{6}{*}{3} & \multicolumn{6}{|c|}{$\%$ partikel batok kelapa terhadap partikel kayu glugu } \\
\hline & $90 \%$ & 3 buah & 3 buah & 3 buah & 3 buah & 3 buah \\
\hline & $80 \%$ & 3 buah & 3 buah & 3 buah & 3 buah & 3 buah \\
\hline & $70 \%$ & 3 buah & 3 buah & 3 buah & 3 buah & 3 buah \\
\hline & $60 \%$ & 3 buah & 3 buah & 3 buah & 3 buah & 3 buah \\
\hline & $50 \%$ & 3 buah & 3 buah & 3 buah & 3 buah & 3 buah \\
\hline \multirow[t]{2}{*}{4} & Partikel batok kelapa & & & & & \\
\hline & $100 \%$ & 3 buah & 3 buah & 3 buah & 3 buah & 3 buah \\
\hline
\end{tabular}

\section{Sumber: Hasil penelitian}

\section{HASIL DAN PEMBAHASAN}

Setelah semua benda uji dibuat dan dikelompokkan sesuai Tabel 1, kemudian dilakukan pengujian kerapatan papan partikel, serapan air, modulus patah, modulus lentur dan ketahanan terhadap suhu tinggi. Hasil pengujian dijelaskan pada sub bab berikut.

\section{Kerapatan papan partikel}

Hasil pengujian kerapatan papan partikel dapat dilihat pada Tabel 2. Kurva hubungan antara kerapatan papan partikel dengan persentase partikel batok kelapa terhadap partikel kayu dapat dilihat pada Gambar 1

Tabel 2. Hasil Pengujian Kerapatan Papan Partikel

\begin{tabular}{cccc}
\hline No. & Benda uji & Kode benda uji & Kerapatan $\left(\mathbf{k g} / \mathbf{c m}^{2}\right)$ \\
\hline 1 & $\%$ partikel batok kelapa terhadap partikel kayu sengon & \\
$90 \%$ & K-S90 & 0,66 \\
$80 \%$ & K-S80 & 0,71 \\
$70 \%$ & K-S70 & 0,67 \\
$60 \%$ & K-S60 & 0,64 \\
& K-S50 & 0,60 \\
\hline 2 & $\%$ partikel batok kelapa terhadap partikel kayu nangka & \\
$90 \%$ & K-N90 & 0,67 \\
& K-N80 & 0,69 \\
& $70 \%$ & K-N70 & 0,66 \\
$60 \%$ & K-N60 & 0,61
\end{tabular}


Dian Sestining Ayu, Edi Kurniadi, Ketahanan Papan Partikel terhadap Suhu Tinggi, Serapan Air dan Perilaku Patah

\begin{tabular}{|c|c|c|c|}
\hline No. & Benda uji & Kode benda uji & Kerapatan $\left(\mathrm{kg} / \mathrm{cm}^{2}\right)$ \\
\hline & $50 \%$ & K-N50 & 0,59 \\
\hline \multirow[t]{6}{*}{3} & $\%$ partikel & apa terhadap part & lugu \\
\hline & $90 \%$ & K-G90 & 0,70 \\
\hline & $80 \%$ & K-G80 & 0,72 \\
\hline & $70 \%$ & K-G70 & 0,69 \\
\hline & $60 \%$ & K-G60 & 0,64 \\
\hline & $50 \%$ & K-G50 & 0,61 \\
\hline 4 & $\begin{array}{c}\text { Partikel bat } \\
100 \%\end{array}$ & K-100 & 0,66 \\
\hline
\end{tabular}

Sumber: Hasil Penelitian

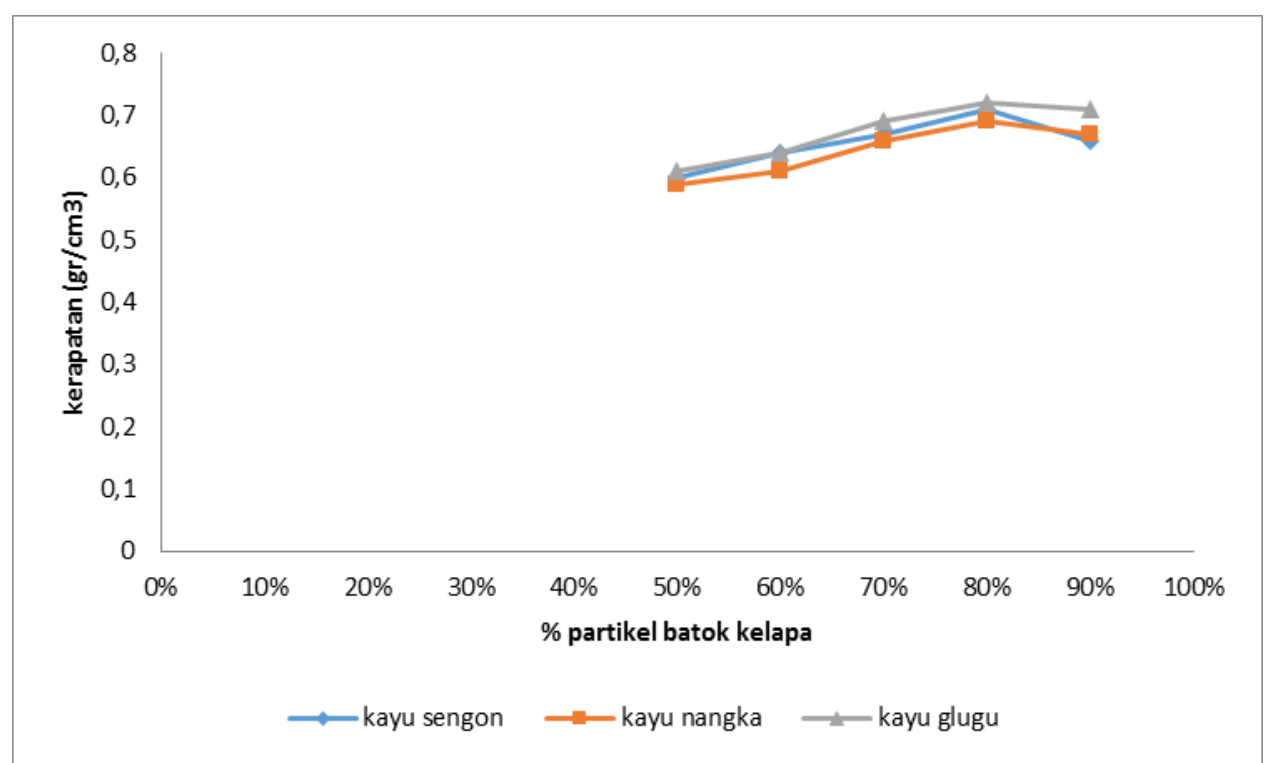

Gambar 1. Hubungan Kerapatan Papan Partikel dan \% Partikel Batok Kelapa

\section{Serapan Air}

Hasil pengujian serapan air papan partikel dapat dilihat pada Tabel 3. Kurva hubungan antara serapan air papan partikel dengan persentase partikel batok kelapa terhadap partikel kayu dapat dilihat pada Gambar 2.

Tabel 3. Hasil Pengujian Serapan Air Papan Partikel

\begin{tabular}{cccc}
\hline No. & Benda uji & Kode benda uji & Serapan air (\%) \\
\hline 1 & $\%$ partikel batok kelapa terhadap partikel kayu sengon \\
$90 \%$ & K-S90 & 15,29 \\
$80 \%$ & K-S80 & 17,31 \\
$70 \%$ & K-S70 & 21,88 \\
$60 \%$ & K-S60 & 29,22 \\
& K-S50 & 31,34 \\
\hline 2 & $\%$ partikel batok kelapa terhadap partikel kayu nangka \\
$90 \%$ & K-N90 & 14,22 \\
& K-N80 & 16,34 \\
& $70 \%$ & K-N70 & 19,77 \\
$60 \%$ & K-N60 & 23,19 \\
$50 \%$ & K-N50 & 29,22 \\
\hline
\end{tabular}




\begin{tabular}{cccc}
\hline No. & Benda uji & Kode benda uji & Serapan air (\%) \\
\hline 3 & $\%$ partikel batok kelapa terhadap partikel kayu glugu & \\
& $90 \%$ & K-G90 & 13,26 \\
& $80 \%$ & K-G80 & 15,61 \\
$70 \%$ & K-G70 & 17,35 \\
& $60 \%$ & K-G60 & 20,66 \\
& $50 \%$ & K-G50 & 25,68 \\
\hline 4 & Partikel batok kelapa & K-100 & 14,25 \\
\hline
\end{tabular}

\section{Sumber: Hasil Penelitian}

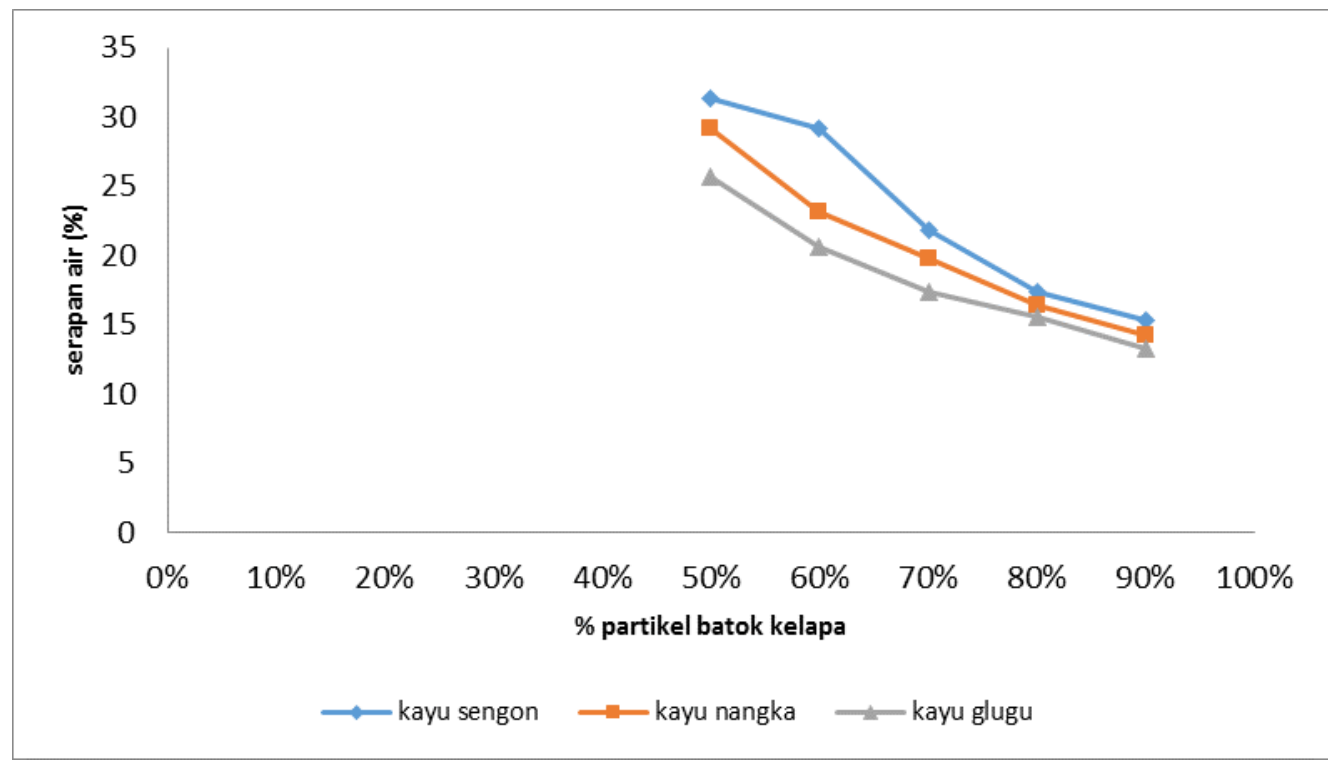

Gambar 2. Hubungan Serapan Air Papan Partikel dan \% Partikel Batok Kelapa

\section{Modulus Patah}

Hasil pengujian modulus patah papan partikel dapat dilihat pada Tabel 4. Kurva hubungan antara modulus patah papan partikel dengan persentase partikel batok kelapa terhadap partikel kayu dapat dilihat pada Gambar 3.

Tabel 4. Hasil Pengujian Serapan Air Papan Partikel

\begin{tabular}{cccc}
\hline No. & Benda uji & Kode benda uji & Modulus elastisitas $\left(\mathbf{k g} / \mathbf{c m}^{2}\right)$ \\
\hline 1 & $\%$ partikel batok kelapa terhadap partikel kayu sengon & \\
$90 \%$ & K-S90 & 37,22 \\
$80 \%$ & K-S80 & 44,66 \\
$70 \%$ & K-S70 & 47,75 \\
$60 \%$ & K-S60 & 40,32 \\
$50 \%$ & K-S50 & 31,22 \\
\hline 2 & partikel batok kelapa terhadap partikel kayu nangka \\
$90 \%$ & K-N90 & 35,21 \\
$80 \%$ & K-N80 & 39,82 \\
$70 \%$ & K-N70 & 44,88 \\
$60 \%$ & K-N60 & 41,63 \\
$50 \%$ & K-N50 & 33,67 \\
\end{tabular}




\begin{tabular}{cccc}
\hline No. & Benda uji & Kode benda uji & Modulus elastisitas $\left(\mathbf{k g} / \mathbf{c m}^{2}\right)$ \\
\hline 3 & $\%$ partikel batok kelapa terhadap partikel kayu glugu & \\
& $90 \%$ & K-G90 & 37,22 \\
& $80 \%$ & K-G80 & 42,97 \\
$70 \%$ & K-G70 & 47.89 \\
& $60 \%$ & K-G60 & 41,69 \\
& $50 \%$ & K-G50 & 33,65 \\
\hline 4 & Partikel batok kelapa & K-100 & 36,35 \\
\hline
\end{tabular}

Sumber: Hasil Penelitian

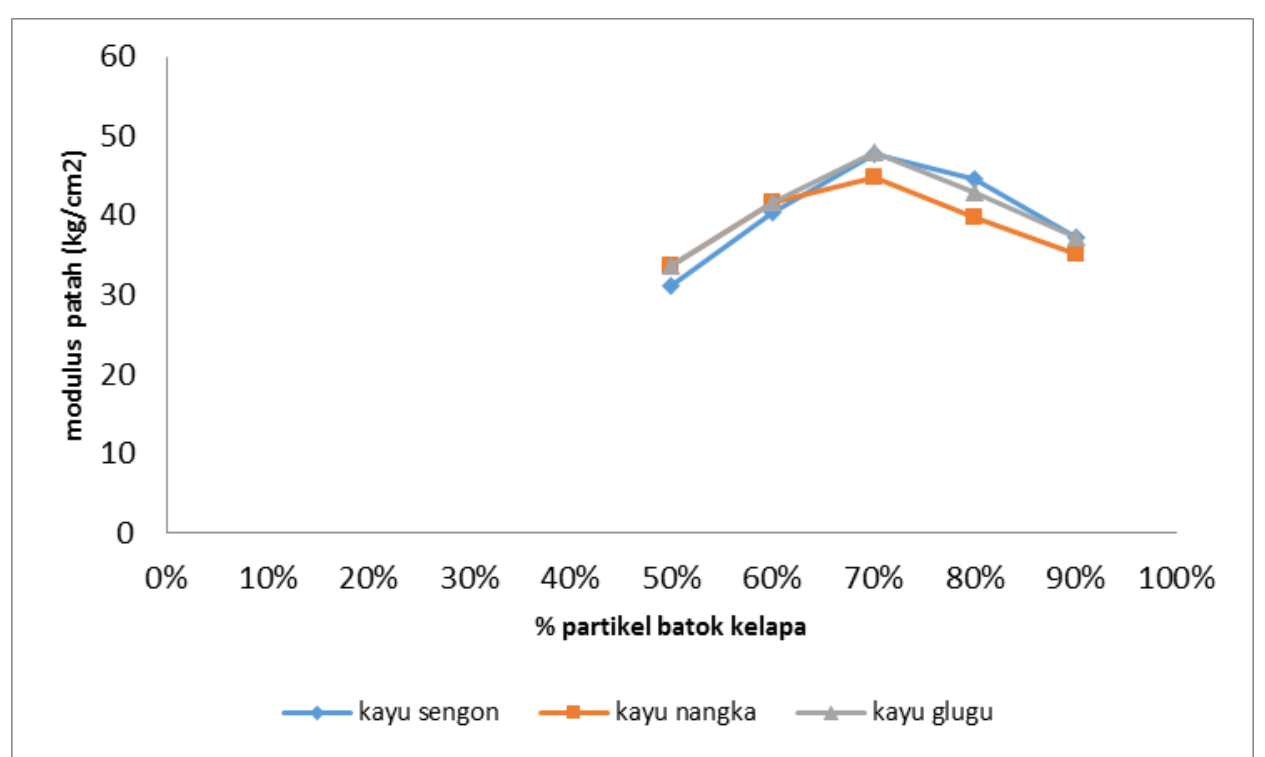

Gambar 4. Hubungan Modulus Patah Papan Partikel dan \% Partikel Batok Kelapa

\section{Modulus Elastisitas}

Hasil pengujian modulus elastisitas papan partikel dapat dilihat pada Tabel 5. Kurva hubungan antara modulus elastisitas papan partikel dengan persentase partikel batok kelapa terhadap partikel kayu dapat dilihat pada Gambar 4.

Tabel 5. Hasil Pengujian Serapan Air Papan Partikel

\begin{tabular}{cccc}
\hline No. & Benda uji & Kode benda uji & Modulus elastisitas $\left(\mathbf{k g} / \mathbf{c m}^{2}\right)$ \\
\hline 1 & $\%$ partikel batok kelapa terhadap partikel kayu sengon & \\
& $90 \%$ & K-S90 & 72,21 \\
$80 \%$ & K-S80 & 73,68 \\
$70 \%$ & K-S70 & 76,65 \\
$60 \%$ & K-S60 & 68,76 \\
& K-S50 & 45,22 \\
\hline 2 & $\%$ partikel batok kelapa terhadap partikel kayu nangka \\
& K-N90 & 67,43 \\
& $80 \%$ & K-N80 & 68,66 \\
$70 \%$ & K-N70 & 72,26 \\
$60 \%$ & K-N60 & 57,33 \\
$50 \%$ & K-N50 & 49,45 \\
\end{tabular}




\begin{tabular}{cccc}
\hline No. & Benda uji & Kode benda uji & Modulus elastisitas $\left(\mathbf{k g} / \mathbf{c m}^{2}\right)$ \\
\hline 3 & $\%$ partikel batok kelapa terhadap partikel kayu glugu & \\
& $90 \%$ & K-G90 & 69,85 \\
& $80 \%$ & K-G80 & 72,98 \\
$70 \%$ & K-G70 & 75,21 \\
& K-G60 & 63,25 \\
& $50 \%$ & K-G50 & 59,21 \\
\hline 4 & Partikel batok kelapa & K-100 & 65,45 \\
\hline
\end{tabular}

Sumber: Hasil Penelitian

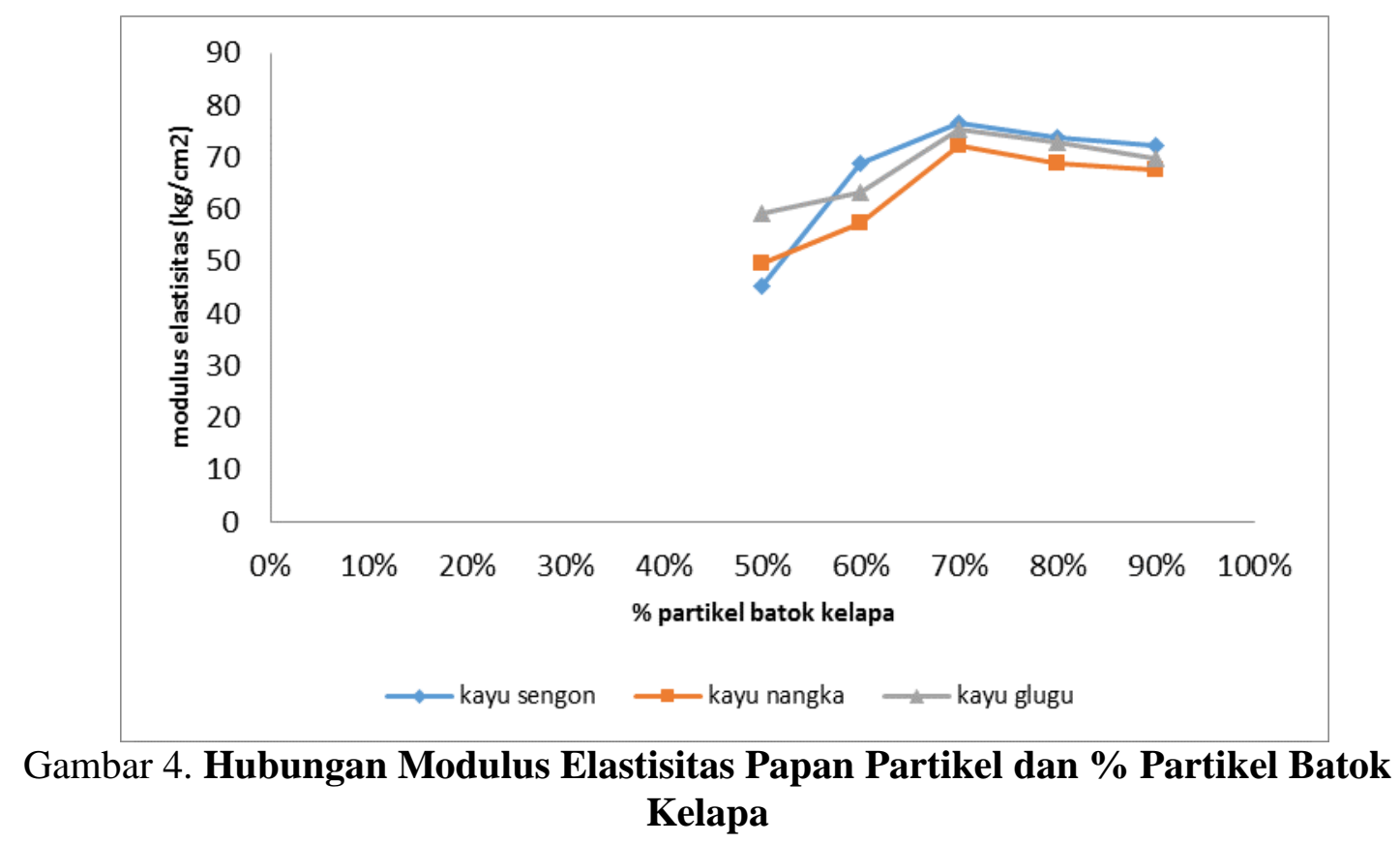

\section{Pembahasan Hasil Penelitian}

Berdasarkan data hasil pengujian dan analisis diperoleh hasil bahwa kerapatan papan partikel dan analisis diperoleh hasil bahwa kerapatan papan partikel akan mencapai optimum pada komposisi $80 \%$ partikel cangkang sawit dan $20 \%$ partikel kayu glugu. Menurut SNI kerapatan bernilai 0,4-0,8 gr/cm3. Papan partikel memiliki nilai kerapatan yang relatif tinggi disebabkan karena pemberian tekanan pada saat pengempaan yang cukup tinggi sehingga terjadi terjadi pemampatan yang berlebihan.

Pada pengujian serapan air, semakin besar persentase berat cangkang kelapa sawit maka nilai serapan air akan semakin rendah. Menurut SNI besarnya serapan air papan partikel tidak boleh lebih dari $20 \%$. Hasil penelitian menunjukkan bahwa syarat tersebut dapat dipenuhi pada persentase berat partikel cangkang kelapa sawit 70\%, 80\% dan 90\%. Cangkang kelapa sawit merupakan material yang keras dan kemampuan serapan airnya rendah. Proporsi cangkang 
kelapa sakit yang cukup banyak memberikan dampak serapan airnya juga rendah.

Pada pengujian modulus patah papan partikel, modulus patah terbesar terjadi pada komposisi 70\% partikel cangkang kelapa sawit dan 30\% partikel kayu glugu yaitu 46.89 $\mathrm{kg} / \mathrm{cm}^{2}$. Secara keseluruhan nilai modulus patah paling besar pada tiga jenis benda uji terjadi pada komposisi $70 \%$ partikel cangkang sawit dan 30\% partikel kayu. Nilai modulus patah menurut SNI adalah $20,4 \mathrm{~kg} / \mathrm{cm} 2$. Tingginya nilai modulus patah pada semua benda uji disebabkan disebabkan karena kurangnya akurasi dalam proses pengempaan yang bisa mengakibatkan nilai kerapatan dan modulus patah melebihi nilai yang disyaratkan.

Pada pengujian modulus elastisitas, nilai terbesarnya adalah $74,99 \mathrm{~kg} / \mathrm{cm}^{2}$ pada benda uji dengan komposisi 70\% partikel cangkang kelapa sawit dan 30\% partikel kayu glugu. Menurut SNI modulus elastisitas papan partikel adalah $82 \mathrm{~kg} / \mathrm{cm}^{2}$. Berdasarkan hasil pengujian terlihat bahwa semua nilai modulus elastisitas benda uji tidak ada yang melebihi batasan SNI.

Pengujian tentang ketahanan papan partikel terhadap suhu tinggi belum bisa dilakukan karena terdapat ketidaksesuaian antara metode pengujian dengan alat yang tersedia

\section{KESIMPULAN}

\section{Kesimpulan}

Berdasarkan hasil pengujian, didapatkan hasil kesimpulan sebagai berikut

1. Papan partikel dengan komposisi $100 \%$ partikel batok kelapa memberikan nilai kerapatan $0,66 \mathrm{gr} / \mathrm{cm}^{3}$, serapan air $14,25 \%$, modulus patah $36,359 \mathrm{~kg} / \mathrm{cm}^{2}$ dan modulus elastisitas $65,45 \mathrm{~kg} / \mathrm{cm}^{2}$.

2. Papan partikel mendapatkan nilai kerapatan optimum $0,72 \mathrm{gr} / \mathrm{cm}^{3}$ pada campuran $80 \%$ partikel batok kelapa dan 20\% partikel kayu glugu. Serapan air bernilai optimum 13,26\% pada komposisi $90 \%$ partikel batok kelapa dan $10 \%$ partikel kayu glugu. Modulus patah bernilai optimum pada komposisi 70\% partikel batok kelapa dan 30\% partikel kayu glugu yaitu $47.89 \mathrm{~kg} / \mathrm{cm}^{2}$. Modulus elastisitas nilai terbesarnya adalah $75,21 \mathrm{~kg} / \mathrm{cm}^{2}$ pada benda uji dengan komposisi 70\% partikel cangkang kelapa sawit dan 30\% partikel kayu glugu.

3. Komposisi campuran terbaik yang mampu menghasilkan nilai kerapatan, serapan air, modulus patah dan modulus elastisitas bernilai optimum terdapat pada proporsi campuran antara 70-90\% partikel batok kelapa dan 30-10\% partikel kayu. 


\section{Saran}

Berdasarkan hasil penelitian, diberikan saran sebagai berikut.

1. Perlu dilakukan uji pengaturan yang akurat dalam proses pengempaan sehingga sidapatkan papan partikel dengan kerapatan ideal

2. Penelitian bisa dikembangkan dengan menggunakan bahan perekat yang lain dalam pembuatan papan partikel.

\section{UCAPAN TERIMA KASIH}

Ucapan terima kasih disampaikan kepada semua pihak yang mendukung terselenggaranya penelitian ini. Secara khusus ucapan terima kasih disampaikan kepada Jajaran Pengelola Departemen Teknik Sipil SV UGM, Kepala Laboratorium Struktur Departemen Teknik Sipil SV UGM, rekan peneliti dan mahasiswa yang membantu proses penelitian.

\section{DAFTAR PUSTAKA}

Anonim. (2006). Standar Nasional Indonesia (SNI) 03-2105. Jakarta: Badan Standarisasi Nasional.

Dewojati. (2014). Cangkang Keong Mas Sebagai Bahan Alternatif Papan Partikel (Studi Kasus Dengan Penambahan Kayu Mahoni dan Kayu Glugu) (Tugas Akhir). Program Diploma Teknik Sipil, SV, UGM, Yogyakarta.

Iskandar, O. (2009). Uji Potensi Pemanfaatan Kulit Kopi di Kabupaten Aceh Tengah Menjadi Papan Partikel Dengan Menggunakan Perekat Urea Formaldehida dan Termoplastik (Tesis S2). Teknik Sipil, UGM, Yogyakarta

Isroful, F.(2011). Pengolahan Papan Partikel Dari Serabut Kelapa Dengan Pelapis Batang Pisang, Tugas Akhir Jurusan Teknik Sipil UNM, Malang

Kollman., F. F. P., and Wilfred, A Jr. C.(1975). Principles of WoodScience and Technology 1 - Solid Wood, Allea and Union Publisher.

Maloney, T. M .(1997). Modern Particle Board and Dry Process Fiberboard Manufacturing. USA: Miller Freeman Publ.

Prayitno, T. A. (1995). Perekatan Kayu, Gadjah Mada University Press, Yogyakarta.

Sulastiningsih, I. M., dkk.(2014). Pengaruh Komposisi Arah Lapisan Terhadap Sifat bambu Komposit, Jurnal penelitian Hasil Hutan 